\title{
The feminism of an antifeminist in Carmen Martín Gaite's Cuadernos de todo
}

\author{
Maria-José Blanco
}

\begin{abstract}
In the 1960s Carmen Martín Gaite (1925-2000) began writing what she called her 'cuadernos de todo', one of her main preoccupations during this period being the situation of women and the family in society. However, the author always rejected the 'feminist' label, to the extent that she even called herself an 'antifeminist'. In this article, I examine the first 'cuadernos de todo', focusing on the author's ideas about women in society. Drawing on Julia Kristeva's (1986) article 'Women's time', I indicate the emergence in Martín Gaite's notebooks of some of the ideas that would be part of the second wave of the 1970s feminism that Kristeva's work helped to catalyse. Even though ideas of 'difference feminism' did not reach Spain until much later, I will argue that Martín Gaite nonetheless 'proposed' a new kind of feminism, different from the man/woman dichotomy upon which much second wave feminism rested, a polyphonic feminism where women could, on the one hand, embrace maternity and, yet, on the other, envisage other social roles.
\end{abstract}

Keywords: Carmen Martín Gaite; Julia Kristeva; women in 1960s Spain; women’s time; misogyny; feminism and antifeminism

\section{Introduction}

Celebrated Spanish author Carmen Martín Gaite (1925-2000) began writing what she called her 'cuadernos de todo' ['notebooks of everything'] ${ }^{1}$ in the 1960s. These notebooks, which she kept for nearly forty years, are considered here as diaries in which she wrote her ideas and thoughts, and maintained a dialogue with the writers she was reading at the time. ${ }^{2}$ The first 'cuaderno', a birthday present from her fiveyear-old daughter, set a trend for the early notebooks in which Martín Gaite reflected on capitalism and the state of women in contemporary Spanish society, contrasting her ideas with readings of José Ortega y Gasset, Bertrand Russell, Thorstein Veblen, Friedrich Engels, Denis de Rougemont, George Simmel, Erich Fromm, Evelyne Sullerot, Simone de Beauvoir and Simone Weil. She left about eighty notebooks, Cuadernos de todo being published in 2002, edited by Maria Vittoria Calvi, and containing a total of thirty-six 'cuadernos' plus a few pages of 'notas fugaces' ['fleeting notes']. Martín Gaite used her first two notebooks mainly to reflect on society and women in Spain. From the third notebook onwards, while themes relating to women such as solitude or the passing of time continued to have a place, albeit not in so much depth, she began to concentrate more on themes of narration and the process of writing. ${ }^{3}$ 
The first three 'cuadernos' are especially important since they form the basis for the rest of the notebooks that Martín Gaite continued writing for over forty years. In this article I examine some of the key themes that these three notebooks reflected on: marriage, motherhood, housework, women in the paid workforce, and women's friendships. First, I contextualize these themes in relation to the changing situation of women in Spanish society of the 1960s. Secondly, I study the 'cuadernos' themselves and identify some examples of what have been considered as antifeminist or misogynist remarks. Thirdly, drawing on Julia Kristeva's article, 'Women's time' (1986), especially her concept of 'generations' of feminism, I indicate the emergence in Martín Gaite's notebooks of some of the ideas that would be part of second wave feminism of the 1970s, which Kristeva's work helped to catalyse. Even though Martín Gaite referred to herself an antifeminist, ${ }^{4}$ I conclude by suggesting that, despite herself, some of her ideas can be recognized as feminist, ideas which she offered to the women of her time through the publication of her novels, short stories and articles.

\section{Spain in the 1960s}

Martín Gaite's first three 'cuadernos' cover a period of six years, from December 1961 to August 1967, years that mark the beginning of a transition in Spanish society, culminating in 1975 with Franco's death. The political repression of the postwar years up to the end of the 1950s relaxed as the frontiers of Spain were opened in the 1960s to foreign tourists who brought money and consumerist culture to what was still a very backward society. As Alex Longhurst suggests: 'The arrival of foreign tourists in large numbers, with the consequent influx of Spanish workers, including many women, to the Mediterranean resorts, also affected the cultural reorientation of ordinary Spaniards' (Longhurst 2000: 19). These years are known as the age of 'desarrollismo' [developmentalism].

In this period, Spain began to see middle-class women going out to work, ${ }^{5}$ demonstrating that they also could have a public place in this newly developing society. Yet, at the same time, women still had a very clear role in the family as housewives and mothers. As Rosa Pardo comments in her 'El feminismo en España: breve resumen, 1953-1985' (1988) ['Brief summary of Spanish feminism'], in the 1960s changes such as emigration and the incorporation of women into the paid workforce revealed the extent of gender and class inequalities. These are also the years in which the first feminist groups started working in 'la clandestinidad' (Pardo 1988: 133) ['underground']. Martín Gaite is thus writing during years of social and economic change, and reflecting as a critic of her time on those changes, which Spanish society had not yet assimilated. Her own reading, such as Thorstein Veblen's Teoria de la clase ociosa (1899) [The Theory of the Leisure Class: An Economic Study of Institutions], helped her reflect on Spain's economic development and its impact on women (Martín Gaite 2002: 68). Georg Simmel's 'Cultura femenina' ['Female culture', in Philosophische Kultur (1911)] encouraged her to reflect on the more specific role of women in society (72-6). At the time, the notebooks would have served Martín Gaite as an escape valve for putting into writing ideas she could not have made public, since Francoist censorship was still in operation. 


\section{The first notebooks: a critical view of women in society}

In Martín Gaite's first novels and short stories, a clear but subtle critique of Spanish society and the position of women is evident but she has been criticized by feminist scholars for portraying only women who remain in their traditional roles rather than strong female characters. ${ }^{6}$ Similarly, in articles published during the 1960 s, Martín Gaite's criticisms are directed more at the society women live in than at women themselves. ${ }^{7}$ However, in her 'cuadernos', her remarks are harsher and are aimed at women directly, and indeed at times she even seems to despise women. She also writes about 'women' or 'they' as if she was not one, a strategy that Laura Freixas (2006: 4) identifies as misogynist. ${ }^{8}$ As mentioned above, Martín Gaite has even called herself an antifeminist: 'Yo soy antifeminista. Yo aspiro a la libertad. Las feministas hablan de libertad, pero la llevan como una pedrada para arrojársela a la cara a los demás' (cited in Escartín Gual 2003: 194) ['I am an anti-feminist. I aspire to freedom. Feminists talk about freedom but they wear it as a stone to throw in other people's faces']. As we will see in the examples that follow, Martín Gaite expresses a strongly negative view of women in society in her first 'cuadernos'. However, as I shall go on to argue, if we situate the author's comments in the context in which they were written, it becomes clear that she was also reflecting on a changing society. What she actually proposes is that women should start thinking about their new roles; they should be critical and analytical about their choices and they should act from an informed and intelligent position.

In the first 'cuaderno', for example, Martín Gaite explicitly criticizes feminists: 'Mientras hagan [las mujeres feministas] todo lo que hacen en función de "no ser menos que los hombres" no habrán abandonado su condición satélite' (Martín Gaite 2002: 33) ['While (feminist women) continue doing everything they do in order "not to be less than men" they will not have abandoned their satellite condition']. This point is also expanded in more general terms: 'Cuando una mujer no pretenda demostrar ni que es mujer ni que deja de serlo y se entregue a cualquier quehacer o pensamiento desde su condición sin forzarla ni tampoco enorgullecerse de ella, sólo entonces será persona libre' (33) ['Only when a woman stops trying to demonstrate that she is or is not a woman and starts giving herself to any task or thought relating to her condition without forcing it or being proud of it, only then will she be a free person']. Such ideas about women who wished to occupy the same sphere as men, abandoning, in some cases, their traditional role as mothers, were represented in Martín Gaite's fiction by female characters who decide not to be mothers due to their feminist ideas. In her fiction Martín Gaite seems to be putting into her characters the ideas she is discussing in her 'cuadernos', either her own ideas or the ideas she reads about or hears in the streets. For example, in Retahilas (1974) [Strings], the female protagonist, Eulalia says: 'En España [...] o eres madre o te haces persona' (Martín Gaite 2003: 106) ['In Spain (...) either you are (become) a mother or you become a person']; this gives her the perspective of the feminists Martín Gaite is criticizing in her diaries. She also uses the male protagonist, David Fuente, in the novel Ritmo lento (1963) [Slow Rhythm] who tries to convince his girlfriend of the need for women to fight against their traditional roles, showing the side of men who 
think themselves feminist, understanding the plight of women and who want them to follow their 'orders' to have a better life. Martín Gaite's short stories, on the other hand, are populated by middle-class women who have nothing to do all day except go to the hairdresser and wait for their husbands to take them out for a walk after work, as in 'Tarde de tedio' (Martín Gaite 2007: 152-61) ['Afternoon of tedium'], or by working-class women who are blamed by their employers for the state of the house or the children, as in 'La tata' (259-69) ['The nanny'].

In the first 'cuaderno', Martín Gaite's target is women seeking independence through paid work: 'Las mujeres que tratan de independizarse hoy día arreglan el problema desde fuera. Imitan los gestos, la actividad, la libertad externa del varón. Sin haber conseguido ni de lejos la interna' (Martín Gaite 2002: 45) ['Women who try to be independent nowadays solve the problem from the outside. They imitate the gestures, the activities, the external freedom of men, without having achieved anywhere near their inner freedom']. Here, Martín Gaite seems to believe that women simply want to work in order to show men that they are able, in her words: 'para sentirse más revalorizadas como hembras, como presa aun más deseable' (46) ['To feel better valued as females, as an even more desirable prey']. She believes in work as a means of satisfaction for one's own self, not to convince others: 'Pero es que una persona no tiene que darse a valer. Tiene que hacer bien las cosas que hace, tiene que hacerlas de verdad, entregarse a lo que haga. Tiene que hacer algo, no fingir que lo está haciendo' (46) ['A person should not make herself valued. She has to do things well, she has to do them for real, committing herself to what she does. She really has to do something not just pretend she is doing it']. The notion of 'darse a valer' ['to make oneself valued'] is key here. In the industrial revolution, when men began leaving the household to work outside the home and earn wages, the value of money changed the value of work. This undermined the work done by women, especially in the home, caring for the children and managing the household economy. Referring to the changes in Spanish society from a rural to an urban population, Moreno Sardá documents how these spatial changes (from country to city) also changed the way work was valued as women also began to incorporate themselves into urban life. With the modernization of the household, housework was devalued, money being the measure to value work: 'tanto cobras, tanto vales, tanto eres; en consecuencia, toda actividad no remunerada significa actividad devaluada' (Moreno Sardá 1988: 87) ['the more you earn, the more you are worth, the more you are; in consequence, all unpaid activity means devalued activity'].

Martín Gaite's comments show that she considered that the real issue was in the way society valued work, so that: 'El sentirse valorada una mujer tiene gran relación con la independencia económica' (Martín Gaite 2002: 74) ['To feel valued as a woman is closely related to economic independence']. She believed that women should value their own work in a different way: 'Si la consideración de ama de casa fuera mayor, a las mujeres les gustaría más ser amas de casa' (82) ['If the respect for housewives was greater, women would like being housewives better']. Thus she defends the work done by women in the home by investing it with greater value than was generally acknowledged: 'Yo no digo que una mujer tenga que dedicarse forzosamente a tareas 
caseras; digo que si las hace debe transcenderlas [...] crear algo con él' (81) ['I am not saying that a woman should be forced to do housework; I say that if she does it, she should transcend it (...) create something with it']. She argues for women's house and caring work to be considered as generosity on their part, and she would like women to think about their work in the home in a positive way, and as an opportunity for reflection: 'se ha dado en confundir el sosiego con la inmanencia, ' la pasividad, la cerrilidad, la pereza mental y demás actitudes viciosas y descarriadas que el sosiego y el silencio han tenido una parte meramente accidental' (93) ['They have confused peace with immanence, passivity, uncouthness, mental laziness and other flawed and misleading attitudes, of which peace and quiet have been a mere accidental part']. That space for reflection, which men, she suggests, generally do not have, is what women should embrace instead of rejecting.

The peace, which Martín Gaite proposes as the enviable preserve of women in the home, can, however, be experienced by men who decide to abandon 'historical time', the time of 'honor y gloria' (94) ['honour and glory'], and retire to reflect, choosing 'silencio y sosiego' (94) ['peace and quiet'], like, for example, some of the philosophers and sociologists whose works she was reading at the time and with whom she maintains a dialogue in her diary pages. While some men may actively choose to retire and reflect, women, in Martín Gaite's view, passively suffer this space of silence and peace as a punishment that has, she believes, its origins in their childhood (94). Of course, in this Martín Gaite is referring only to women who are sufficiently privileged to have free time to reflect on life, rather than worrying about money and other life concerns. However, in her notebooks, she is not alert to this and does not distinguish between social groups. ${ }^{10}$ Another aspect of women's lives that Martín Gaite commented on extensively is motherhood. She considers caring for one's child and facilitating his or her development towards independence as an important part of the role of mothers in society, yet she criticizes women who live through their children: 'no es "razón de su vida", es decir "objecto de trabajo, atención y reflexión", sino ciegamente su vida' (80) ['it is not "the meaning of her", I mean as "an object of work, attention and reflection", but unthinkingly her life']. ${ }^{11}$ Martín Gaite sees the role of the mother as one which facilitates the child's development by giving them freedom to understand the world freely, giving them the tools to reach 'criterio autónomo' (80) ['independent judgement'].

\section{Women's time}

In 'Women's time', Julia Kristeva famously identifies two 'generations' ${ }^{12}$ of feminists. The first, exemplified by the suffragists and existential feminists (such as Beauvoir), demanded equal rights with men, rejecting 'the attributes traditionally considered feminine or maternal' (Kristeva 1986: 193). A second 'phase', 'women who came to feminism after May 1968' (194) and/or who came from a 'psychoanalytical experience' (194) (such as feminist thinkers Luce Irigaray and Hélène Cixous), embraced maternity and difference; for these feminists, professional life and maternity are compatible and they find the experience of motherhood 'indispensable to their discovery, not of the plenitude, but of the complexity of the female experience' (205). 
For her part, referring to the supposed independence women had attained in the 1960s, Martín Gaite acknowledged in her notebooks that women were still unequal to men in society: 'Pasadas sus euforias de proposito feministas tal vez empiecen a intuir que a pesar de todo estan debajo' (Martín Gaite 2002: 75) ['After the euphoria has passed, feminists may start to realize that after all, they are below men']. She goes on to distinguish three periods that women had lived through during her lifetime: ' $1^{\text {a }}$ época: aceptación, sumisión; 2a : euforia, rebeldía (feminismo), afirmando tener lo que se tiene (por revancha); $3^{\text {a }}$ (que apunta ahora): descontento, una especie de pérdida de fe en los ideales. Nausea'13 $(75)$ [' $1{ }^{\text {st }}$ period: acceptance, submission; $2^{\text {nd. }}$ : euphoria, rebellion (feminism), affirming what one has (for revenge); $3^{\text {rd }}$ (the one now): disenchantment, a kind of loss of faith in ideals. Anguish (Nausea)']. The 'mujer emancipada' (94) ['emancipated woman'] who has gained either a place in the workforce or emancipation from her husband finds herself, in Martín Gaite's account, empty once she has reached her objective.

However, the way Martín Gaite discusses independent or emancipated women is very patronizing, suggesting that 'they' have no idea of what is really happening in their lives: 'embriagada como está por su primera victoria aun vacilante y poco afirmada de poder entrar y salir, de ser tenida en consideración, de agitarse, y hormiguear entre los varones, de hacer ruido como ellos' (94) ['drunk as she is with her first victory, still shaky and not very confident of being able to come and go, of being listened to, of wriggling and crawling amongst men, of making a noise like them']. Having gained some kind of independence without analysing what that independence entails, women, she thinks, have not achieved anything. They have only changed boredom for solitude (94).

Martín Gaite's ideas about marriage are important for understanding her position in relation to women in Spanish society of the time. For the author, marriage should be a place of friendship and comradeship, and freedom should be fundamental in the relationship, she comments:

Mientras no se deje de ver el matrimonio como una simbiosis [...] pero sin dar a las mujeres la posibilidad de poner la mente a salvo para meditar sobre ese mismo estado matrimonial que limita su horizonte intelectual, no hemos adelantado nada. (120)

[As long as we see marriage as a symbiosis (...) without giving women the possibility to put their mind in a safe environment to reflect about the state of marriage which restricts their intellectual horizon, we have not moved forward.]

According to Martín Gaite, woman's freedom is found in solitude and reflection and this is why she extols the virtues of home life and housework for women. She does not believe that a woman needs to go into a public space to find freedom, as the husband does. Indeed, and contrary to feminist thinking, she is particularly critical of womento-women friendships, referring to 'best friends' as a 'raza horrible' (56) ['horrible race']. Reading Evelyne Sullerot on La Presse féminine (1964) [Women's Magazines], Martín Gaite reflects on the influence of magazines and the 'novela rosa' ['romantic novel'] in promoting women as helpless: 'nunca les señalan la posibilidad de cura por 
medio de la mente o de la razón' (83) ['they never suggest it is possible to improve their situation, through the mind, through reasoning'].

Martín Gaite's ideas about solitude and reflection were developed throughout her career. In her novels and short stories of the 1950s and 1960s women suffer solitude without being able to escape it, but her protagonists of the 1970s start reflecting on their position as women on their own, after the collapse of their marriages. In her 1990s novels, solitude is no longer something to be feared, and women develop as women through reflection while, at the same time, forging a freer and more equal dialogue with men. For example, in Lo raro es vivir (1996) [Living's the Strange Thing (2004)] we meet, for the first time in Martín Gaite's work, a woman who has an equal relationship with her male partner and who decides to become a mother once she has been able to understand her own mother.

In 'Women's time', Kristeva proposes a solution to the 'conflict' between the two 'generations' of feminists, creating a parallel third 'generation' or attitude which will bring 'the demassification of the problematic of difference, which would imply, in a first phase, an apparent de-dramatization of the "fight to death" between rival groups and thus between the sexes' (Kristeva 1986: 209). The need to end the dichotomy and conflict between the sexes is also part of the change that Martín Gaite envisages for women so they can take their place in society:

¿Será inevitable la guerra entre hombre y mujer? ¿Por qué? [...] Por una parte, sería ideal la colaboración inteligente dentro de la estructura matrimonial. [...] Una vez más se impone un arreglo desde dentro no desde fuera. (Martín Gaite 2002: 66)

[Is war between man and woman inevitable? Why? (...) In one way, intelligent collaboration inside the structure of marriage would be ideal. (...) Once more, a solution which comes from the inside not the outside is imperative.]

She considers feminist or women's groups as threatening to that peace between the sexes: 'Lo malo de las ligas de mujeres es que no parece evitable que haya en ellas algo de "lucha contra el enemigo común"' (66) ['The worst thing about women's leagues is that it seems inevitable that there is something in them that seeks "to fight against the common enemy"']. These words echo Kristeva's ideas: 'I see arising, under the cover of a relative indifference towards the militance of the first and second generations, an attitude of retreat from sexism (male as well as female)' (Kristeva 1986: 210). The need to finish with the fight between the sexes is the first step towards real independence.

Although the message this conveys about Martín Gaite's opinion on the state of women is very negative, solitude and anguish being, in her analysis, an intrinsic element of women's new-found freedom and independence, she can nonetheless see the future more positively: 'Aun tendrá que pasar algún tiempo para que con la libertad recién estrenada lleguen a elegir y hagan suyo de verdad ese sosiego que les perteneció' (Martín Gaite 2002: 95-6) ['With the new freedom, some time will have to pass until they will be able to choose and will really make their own that peace which they once possessed']. The future that Martín Gaite sees for this pessimistic 
present is: 'Una aceptación más inteligente de la propia naturaleza' (75) ['A more intelligent acceptance of one's own nature']. She advocates 'una actitud activa y crítica frente a todo lo que se opina' (48) ['an active and critical attitude towards every opinion'], in order to gain independence through reflection.

\section{Conclusion: a feminist reading}

At the beginning of her notebooks Martín Gaite writes:

Yo siento, casi físicamente a veces, las barreras que levanto contra mis pensamientos, a los que pocas veces dejo campo libre [...]. Casi nunca dejamos que un pensamiento nos habite por completo y que llegue en ramificaciones a donde tenga que ir. (Martín Gaite 2002: 27)

[I feel, almost physically sometimes, the barriers which I raise against my thoughts, which I hardly ever allow to range freely (...). We hardly ever allow our thoughts to occupy us completely and through ramifications to reach their destinations.]

The pages of her diaries serve Martín Gaite as places for such reflection. Once published, those thoughts, noted down for her own purposes, risk being taken out of context. The author was writing at a time of change in Spain, a time when women began to have more freedom, women who, for the first time in many years, found themselves as part of a public space, and she was reflecting on the changes and the attitudes of some women at that time. Even though many of her comments about women's choices in relation to that new space are extremely negative, she also foresaw positive possibilities for women. She reflected on the reconciliation of women's traditional roles as mothers and housewives with their newer roles as part of the paid workforce. She saw a future in the way women who wanted to be independent could attain not only an external but also an internal freedom through thought and reflection and those who chose to stay at home and look after their children could find in this kind of work a place of fulfilment. Martín Gaite exhorted women to be responsible for their own actions, to break with the immanence that patriarchal society had conferred on them, and to embrace motherhood and reflect on their roles as mothers and wives - to be able to transcend their traditional situation.

In her first notebooks, Martín Gaite advocated a more creative way for Spanish women to negotiate the new historical period which was dawning in the 1960s, where reflection and intelligence would be integral to those changes. As well as pre-figuring Kristeva's third 'generation' of feminism, this perspective resonates with what Alicia Redondo Goicoechea calls a 'polyphonic feminism': 'Una crítica feminista polifónica hace posible pensar en la producción de las mujeres en sí misma y desde sus múltiples perspectivas, al margen de la dicotomía hombre-mujer' (Redondo Goicoechea 2001: 42) ['A polyphonic feminist critique makes it possible to think about women's contribution in its own right and from its multiple perspectives, removed from the dichotomy man-woman']. It is not possible to exonerate Martín Gaite's notebooks completely from accusations of misogyny, but, by situating her words in the contexts of when and how they were written and of the extent of changes in Spanish society 
of the time and their impact on women, it is possible to recognize the nuances in her thinking and ultimately to discover that there was actually a feminist concealed behind the antifeminist.

\section{Notes}

1. All translations are mine.

2. The notebooks conform to Laura Freixas's definition: 'El diario podría ser [...] una reflexión, en primera persona y enraizada en la cotidianidad, sobre la condición humana y el sentido de la vida' (Freixas 1996: 12) ['A diary may be (...) a reflection, in the first person, rooted in everyday life, about human condition and the meaning of life'].

3. Chapter 3 of my thesis, 'Diaries, Letters and Reflections: Life Writing in Carmen Martín Gaite's Cuadernos de todo and her 1990s Novels', is dedicated to the Cuadernos de todo, considering amongst other themes the relationship between the Cuadernos and Martín Gaite's other published work. There is little published critical work on the Cuadernos de todo to date: see for example Calvi (2004) and Celaya (2007). Only one article (Freixas 2006) concentrates on the first 'cuadernos' and women's issues, although, in this piece, Freixas focuses more on Rosa Chacel's diaries than on Martín Gaite's.

4. I understand 'antifeminist' as those who criticize or oppose feminism or feminist ideas.

5. Many women of the working classes had to work during Franco's years even though the kind of work they did meant they may not have been registered as part of the workforce. The change in numbers of women working outside the home was more noticeable amongst the middle class. The following statistics show the increase in women in paid work from the 1930 s to the 1970 s: 'de un $9 \%$ en 1930 , a un $8,3 \%$ en $1940,15,8 \%$ en $1950,20 \%$ en 1960 y 24\% en 1970' (Moreno Sardá 1988: 88) ['From 9\% in 1930, to $8.3 \%$ in $1940,15.8 \%$ in $1950,20 \%$ in 1960 and $24 \%$ in 1970 '].

6. See Cruz (2002). Mercedes Carbayo Abengózar discusses the ways in which women writers of Martín Gaite's generation managed to denounce the position of women in society through their writing without coming into conflict with the current censorship: 'sin agresividad, pero con firmeza' (Carbayo Abengózar 1998: 54) ['firmly but not aggressively']. In her 'cuadernos' Martín Gaite was able to use much more aggressive vocabulary in relation to the society of the time, as her diaries were not published until after her death.

7. See Martín Gaite (1982), which includes articles such as 'Las mujeres liberadas' (123-31) ['Liberated women'], first published in Triunfo and 'La influencia de la publicidad en las mujeres' (113-21) ['The influence of publicity on women'], published in December 1965 in Cuadernos para el diálogo.

8. Freixas's 2006 article was developed from a paper she presented at a conference in Córdoba (Spain) in 2006 entitled 'La misoginia: tema común en los diarios de Rosa Chacel y de Carmen Martín Gaite' ['Misogyny: a common theme in the diaries of Rosa Chacel and Carmen Martín Gaite'], http://www.edartis.org/pdf/triptico2 cordoba.pdf [accessed 16 January 2008]; the word 'misoginia' ['misogyny'] was dropped for the published version. Also see Caballé (2006), in which Martín Gaite's name appears as one of the Spanish authors identified as using misogynistic remarks in her writing.

9. The existentialist vocabulary of 'transcendence' and 'immanence' in relation to women is to be found in Simone de Beauvoir's The Second Sex, originally published in French in 1949. As Toril Moi explains: 'Beauvoir's main thesis [...] is simple: throughout history, women have been constructed as man's Other, denied the right to her own subjectivity and to responsibility for her own actions. [...] patriarchal ideology presents woman as immanence, man as transcendence' (Moi 1985: 92). The idea of woman as immanence or passive is what Martín Gaite wants women to fight against.

10. Even though, in her short stories, poor women from the cities, women from the countryside and women who work in domestic service are represented, revealing their 
difficulties and contrasting them with the middle-class women she is criticizing, in her diaries, these working-class women hardly have a place.

11. Here, Martín Gaite's points echo child psychologist D. W. Winnicott's notion of the 'good-enough mother': 'The good-enough mother [...] starts off with an almost complete adaptation to her infant's needs, and as time proceeds she adapts less and less completely' (Winnicott 1953: 94).

12. Kristeva states in her article: 'My usage of the word "generation" implies less a chronology than a signifying space, a both corporeal and desiring mental space' (Kristeva 1986: 209).

13. The idea of 'Nausea', as for 'immanence', is a Sartrian existentialist concept.

\section{Works cited}

Caballé, Anna (2006) Una breve historia de la misoginia (Barcelona: Lumen).

Calvi, Maria Vittoria (2004) 'Los cuadernos de todo de Carmen Martín Gaite: lengua y memoria', in La memoria delle lingue: La didattica e lo studio delle lingue della Penisola Iberica in Italia (Messina: Andrea Lippolis), 37-49.

Carbayo Abengózar, Mercedes (1998) Buscando un lugar entre mujeres: Buceo en la España de Carmen Martín Gaite (Malaga: Servicio de Publicaciones de la Universidad).

Celaya, Beatriz (2007) 'El amor es una tara: Cuadernos de todo, de Carmen Martín Gaite', Neophilologus 91.2 (April), 221-41.

Cruz, Jacqueline (2002) 'Replegando la voz: Carmen Martín Gaite y la cocina de la escritura', in Sexualidad y escritura (1850-2000), ed. Raquel Medina and Barbara Zecchi (Barcelona: Anthropos), 249-69.

Escartín Gual, Montserrat (2003) 'Noticias de Carmen Martín Gaite y Retahílas', in Retahilas (Barcelona: Destino), 169-232.

Freixas, Laura (1996) 'Auge del diario ¿intimo? en España', Revista de Occident. El diario intimo: Fragmentos de diarios españoles (1995-1996) 182-3 (July-August), 5-14.

(2006) 'Rosa Chacel, Carmen Martín Gaite: dos reflexiones en torno a mujer y creación', Siglo XXI, literatura y cultura españolas: revista de la Cátedra Miguel Delibes 4, 47-58.

Kristeva, Julia (1986) 'Women's time', in The Kristeva Reader, ed. and introd. Toril Moi (New York: Columbia University Press), 187-213.

Longhurst, Alex (2000) 'Culture and development: the impact of 1960s "desarrollismo"', in Contemporary Spanish Cultural Studies, ed. Barry Jordan and Rikki Morgan-Tamosunas (London: Arnold), 15-28.

Martín Gaite, Carmen (1982) [1972] La búsqueda de interlocutor y otras búsquedas (Barcelona: Destinolibro).

_ (1984) [1963] Ritmo Lento (Barcelona: Anagrama).

(1999) [1996] Lo raro es vivir (Barcelona: Anagrama).

(2002) Cuadernos de todo, ed. Maria Vitoria Calvi (Barcelona: Arete).

(2003) [1974] Retahilas (Barcelona: Destino).

(2004) Living's the Strange Thing, trans. Anne McLean (London: Harvill).

(2007) [1978] Cuentos completos (Madrid: Alianza).

Moi, Toril (1985) Sexual/Textual Politics (London: Methuen).

Moreno Sardá, Amparo (1988) 'La réplica de las mujeres al franquismo', in El feminismo en España: Dos siglos de historia, ed. Pilar Folguera (Madrid: Editorial Pablo Iglesias), 85-110.

Pardo, Rosa (1988) 'El feminismo en España: breve resumen, 1953-1985', in El feminismo en España: Dos siglos de historia, ed. Pilar Folguera (Madrid: Editorial Pablo Iglesias), 133-40. 
Redondo Goicoechea, Alicia (2001) 'Introducción literaria', in Feminismo y misogninia en la literatura española: Fuentes literarias para la historia de las mujeres, ed. Cristina Segura Graiño (Madrid: Narcea), 19-46.

Sullerot, Evelyne (1964) La Presse féminine (Paris: Armand Colin).

Winnicott, Donald W. (1953) 'Transitional objects and transitional phenomena', International Journal of Psycho-Analysis 34, 89-97.

\section{Internet sources}

http://www.edartis.org/pdf/triptico2_cordoba.pdf [accessed 25 October 2008]. 